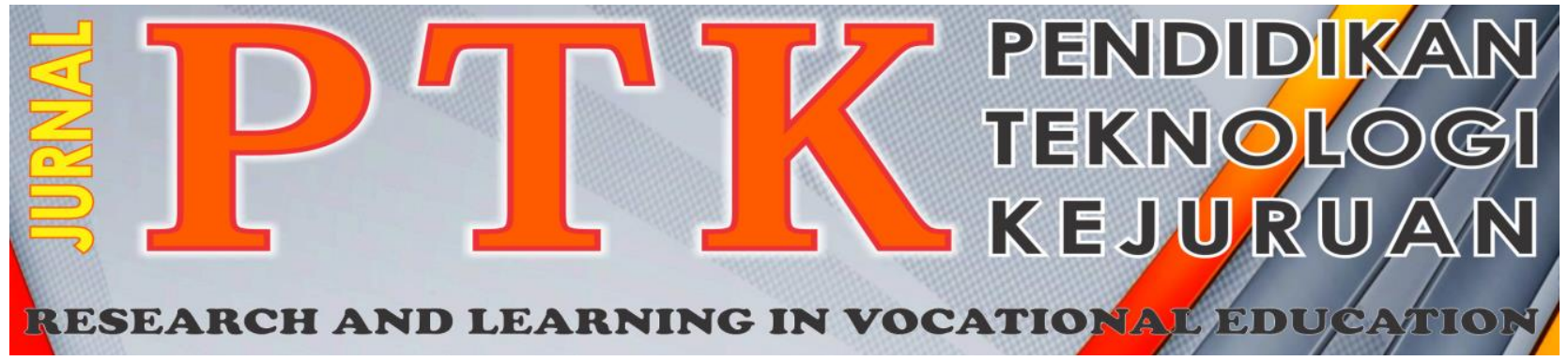

Vol. 1, No. 2 Mei 2018

P-ISSN: 2621-3273

E-ISSN: 2621-1548

\title{
EXSPERT VALIDITY PADA PENGEMBANGAN MODEL PEMBELAJARAN BERBASIS PROYEK E COMMERCE PADA PEMBELAJARAN KEWIRAUSAHAAN
}

\author{
Muharika Dewi ${ }^{1}$, Kasman Rukun ${ }^{2}$ dan Agusti Efi ${ }^{3}$ \\ Universitas Putra Indonesia YPTK ${ }^{1}$, Universitas Negeri Padang ${ }^{2,3}$ \\ "Corresponding author, e-mail: mkea210@gmail.com
}

\begin{abstract}
Abstrak-Ekonomi digital menuntut perubahan dalam penerapan kurikulum pembelajaran kewirausahaan. Relevansi kompetensi dan kebutuhan industri menjadi dasar dalam melakukan inovasi dalam pembelajaran kewirausahaan. Penelitian ini adalah penelitian dan pengembangan pada model pembelajaran berbasis proyek $e$ commerce pada mata kuliah kewirausahaan, model memiliki 8 fase sebagai kerangka acuan dalam melaksanakan pembelajaran, validasi pakar menyatakan bahwa aspek rasionalisasi model, aspek teori pendukung, aspek syntax, aspek sistem sosial, aspek prinsip reaksi, aspek system pendukung, dan aspek dampak instruksional dan dampak pengiring memiliki kategori valid dengan skor $>0.60$. Validasi ini dilakukan oleh lima orang para ahli sebagai validator. Penilaian yang dilakukan pakar selaku validator terkait dengan aspek instruksional dan aspek teknis untuk menghasilkan model pembelajaran dengan isi dan struktur yang berkualitas tinggi. Model baik untuk diterapkan pada pembelajaaran Kewirausahaan berbasiskan produk e commerce untuk meningkatkan kemampuan berwirausaha mahasiswa di era ekonomi digital.
\end{abstract}

Kata kunci : Validasi pakar, model pembelajaran, pembelaran berbasis proyek, kewirausahaan, e commerce.

Abtract-The digital economy demands changes in the application of an entrepreneurial learning curriculum. The orelevance of competence and industry needs becomes the basis for innovation in entrepreneurial learning. This research is research and development on e commerce project based model in entrepreneurship subject, model has 8 phases as reference frame in conducting learning, expert validation states that aspect of model rationalization, supporting theory aspect, syntax aspect, social system aspect, principle aspect reactions, aspects of the support system, and the instructional impact aspect and combat impact have a valid category with a score >0.60. Validation is done by five experts as a validator. Assessment by experts as the validator associated with the aspects of instructional and technical aspects to produce learning models with content and structure of high quality. Good model to apply to ebusiness based e-commerce Entrepreneurship to improve student entrepreneurship ability in the era of digital economy.

Keywords: expert validation, project-based learning, instuctional model, entrepreneurship, e commerce

Copyright @ 2018 JPTK. All rights reserved

\section{Pendahuluan}

UNESCO menetapkan empat pilar pendidikan yaitu: (a) learning to know, (b) learning to do, skill ke competent, (c) learning to live together, dan (d) learning to be, serta penerapan prinsip belajar sepanjang hayat [1] dengan demikian mahasiswa pada Perguruan Tinggi tidak hanya belajar untuk mendapatkan pengetahuan tentang perkembangan globalisasi dan IPTEK namun mahasiswa diharapkan berpartisipasi dan bekerjasama dalam memecahkan masalah dimasyarakat, dan dapat menolong dirinya sendiri dan memiliki kecakapan hidup. Dinamika dunia kerja menuntut penyelenggaran pendidikan harus mampu menghadapi dan mengantisipasi perubahan yang terjadi dengan memanfaatkan berbagai sumber daya yang tersedia untuk menciptakan situasi pembelajaran yang kreatif, inovatif dan adaptif sehingga tercipta lulusan yang kompeten [2]. 
Universitas bertanggung jawab langsung sebagai sumber utama dari peningkatan keterampilan melalui pengembangan kurikulum, dengan tujuan menghasilkan lulusan berkualitas untuk pasar tenaga kerja [3]. Diharapkan lulusan perguruan tinggi menjadi manusia yang mampu bersaing merebut peluang pasar dengan tingkat persaingan yang saat ini semakin tinggi. Maka dibutuhkan keseimbangan antara ilmu pengetahuan yang diperoleh seorang mahasiswa dengan kebutuhan nyata dengan tingkat relevansi pendidikan dan program-program pembelajaran sesuai dengan perkembangan arus globalisasi, teknologi dan informasi dalam ekonomi digital pada saat ini.

Namun beberapa kajian menyebutkan bahwa terdapat permasalahan tidak relevannya kebutuhan industri dengan kemampuan yang dimiliki seorang lulusan Perguruan Tinggi, oleh karena itu peningkatan kompetensi di Perguruan Tinggi dapat meningkatkan peluang kerja lulusannya [4], hal ini menguatkan dugaan bahwa perlu adanya inovasi dan pembaharuan dalam bidang pendidikan dan pengajaran. Demikian pula dengan mata kuliah Kewirausahaan, Dosen sangat membutuhkan inovasi dan perubahan dalam kurikulum pembelajaran. Mengingat pentingnya penguasaan kompetensi ini untuk bersaing di era ekonomi digital, maka Pembelajaran Kewirausahaan selayaknya dirancang untuk memberikan simulasi pada kehidupan yang realitas sehingga mahasiswa dapat menemukan cara praktis belajar berinovasi dan mendapatkan pengalaman nyata dalam berwirausaha [5].

Berdasarkan kajian di atas maka untuk dapat menyelaraskan kemampuan bersaing wirausaha dalam berbisnis di era ekonomi digital maka dibutuhkan model pembelajaran yang mendukung kemampuan mahasiswa agar dapat melaksanakan kegiatan berbisnis melalui pembelajaran berbasis proyek e commerce di Perguruan Tinggi. Project Based Learning adalah pembelajaran yang dirancang untuk menghadapi tantangan perkembangan teknologi yang begitu cepat sehingga dapat mengantisipasi terbatasnya waktu yang disediakan oleh kurikulum untuk menguasai suatu kemampuan teknis [6]. Model ini memiliki metode mengajar belajar yang faktual, berdasarkan masalah yang nyata. Model ini dipandang sesuai dikembangkan untuk melaksanakan pembelajaran kewirausahaan dalam ekonomi digital. Kewirausahaan dengan menggunakan model pembelajaran berbasis proyek pada era internet dengan perangkat pendukung pembelajaran yang disesuaikan dengan kebutuhan pembelajaran dan tujuan pembelajaran agar mahasiswa mampu menjadi seorang wirausaha internet yang menjalankan kegiatan perdagangan elektronik atau e commerce. Wirausaha internet adalah generasi baru wirausaha yang melakukan upaya menjadi pengusaha sukses dengan mendirikan bisnis berbasis internet [7]. Wirausaha internet adalah mereka yang bersaing di internet, dengan meningkatkan intensitas waktu agar mampu menjadi "Hiperkompetitif" dalam menghadapi perubahan sifat lingkungan yang serba cepat dalam berbisnis [8]. Kehadiran model pembelajaran inovatif dengan mempersiapkan mahasiswa mampu berwirausaha melalui internet dipandang menjadi salah satu cara dalam meningkatkan pencapaian tujuan pembelajaran kewirausahaan yang relevan dengan perubahan di era ekonomi digital.

Tujuan dari penelitian ini adalah untuk menjelaskan tentang validitas pakar tentang pengembangan Model Pembelajaran berbasis proyek e commerce pada mata kuliah kewirausahaan untuk universitas.

\section{Tinjauan Pustaka}

\section{A. Entreprenurship}

Kewirausahaan adalah hasil dari suatu disiplin serta proses sistematis penerapan kreativitas dan inovasi dalam memenuhi kebutuhan dan peluang di pasar [9]. Wirausahawan dalam melakukan aktivitas manajemen strategik dimana dalam keputusan mempertimbangkan kekuatan dan kelemahan wirausaha (internal) dan juga peluang dan hambatan yang ada dalam lingkungan usaha (eksternal), bermanfaat untuk individu dan masyarakat [10]. Wirausaha adalah mereka yang mampu memanfaatkan sumber daya yang ada dalam dirinya maupun dalam lingkungan disekirarnya sehingga memiliki nilai komersialitas dan mendatangkan keuntungan melalui inovasi yang dikembangkannya.

\section{B. Model Pembelajaran Berbasis Proyek}

Model pembelajaran merupakan kerangka konseptual yang melukiskan prosedur yang sistematis dalam mengorganisasikan pengalaman belajar untuk mencapai tujuan belajar [11]. Saat seorang pendidik membantu mahasiswa memperoleh informasi, gagasan, skill, nilai, cara berfikir dan tujuan mengekpresikan diri mereka sendiri, kita sebenarnya tengah mengajari mereka untuk belajar, mengajar yang sesungguhnya adalah mengajarkan mahasiswa bagaimana belajar [12]. "Models of teaching is an overall plan, or pattern, for helping students to learn spesific kinds of knowledge, attitudes, or skills" [13]. Kegiatan ini umumnya mencerminkan jenis aktivitas/pekerjaan yang dilakukan dalam kehidupan sehari-hari diluar kelas, pembelajaran ini umumnya dilakukan oleh kelompok pesertadidik yang bekerjasama mencapai 
tujuan bersama. "Pembelajaran berbasis proyek secara umum mempunyai pedoman atau langkah perencanaan (planning), menciptakan (creating), dan pengolahan (processing)". Pembelajaran berbasis proyek adalah suatu model kegiatan di kelas yang berbeda dengan biasanya [14]. Model pembelajaran berbasis proyek merupakan pembelajaran yang efektif untuk diterapkan pada kegiatan pembelajaran [15]. Kegiatan pembelajaran berbasis proyek berjangka waktu lama, antar displin, berpusat pada mahasiswa dan terintegrasi dengan masalah dunia nyata, merupakan pembelajaran inovatif yang berpusat pada mahasiswa (student centered) dan menempatkan dosen sebagai motivator dan fasilitator, dimana peserta didik diberi peluang bekerja secara otonom mengkonstruksi belajarnya.

\section{E Commerce}

Perdagangan elektronik atau yang disebut juga $e$ commerce, adalah penggunaan jaringan komunikasi dan komputer untuk melaksanakan proses bisnis [16]. Pengertian dari e-commerce adalah menggunakan internet dan komputer dengan browser web untuk mengenalkan, menawarkan, membeli dan menjual produk. e commerce adalah bagian dari $e$ business, e commerce merupakan proses pembelian, penjualan ataupun penggantian produk, pelayanan serta informasi dengan menggunakan internet [17]. Dengan demikian $e$ business adalah kegiatan bisnis yang memanfaatkan teknologi elektronika tidak hanya pada pemanfaatan teknologi komputer dan internet. Sedangkan $e$ commerce adalah bagian dari $e$ business. $E$ commerce adalah salah satu implementasi dari bisnis online, berbicara mengenai bisnis online tidak terlepas dari apa yang disebut transaksi seperti electronic commerce, dalam e commerce tedapat aktivitas pembelian, penjualan, pemasaran dan layanan atas produk dan jasa yang ditawarkan melalui kompter dan jaringan internet.

\section{Peluang Wirausaha Internet dan $E$ Commerce}

Pengenalan teknologi informasi dan komunikasi membawa harapan baru untuk para wirausaha. Dengan meningkatnya popularitas Internet dan teknologi komunikasi, konsumen semakin banyak penyelidikan dan pembelian produk melalui jaringan Internet. Salah satu fitur yang menonjol dari Internet adalah pengenalan Web 2.0 yang memungkinkan pengguna untuk membentuk dan memperluas jaringan mereka secara online, fitur ini telah terbukti mampu mendukung badan usaha, khususnya di kegiatan yang berhubungan dengan marketing ( $e$ marketing) [18]. Internet telah membuat interaksi bisnis menjadi multi-aspek, orang bisa melakukan bisnis, seperti membeli sesuatu, bertransaksi, dan menjalankan fungsi-fungsi bisnis melalui internet [17]. Internet merupakan dunia tanpa batas yang dapat dimanfaatkan untuk berbisnis, seperti yang dikemukakan oleh Sulianta mengemukakan bahwa internet yang menciptakan dunia virtual tenyata mampu membangun bisnis nyata dengan keuntungan yang nyata bahkan mampu menjadi sumber penghasilan utama [19]. Berdasarkan teori-teori yang telah dikemukakan tersebut maka dapat dinyatakan bahwa terdapat peluang yang besar dalam meraup keuntungan dari adanya perkembangan perdagangan elektronik menggunakan jaringan internet yang semakin hari semakin besar yang dapat diraih oleh seorang wirausaha. Kerangka Konseptual dari penelitian ini dijelaskan dalam Gambar 1:

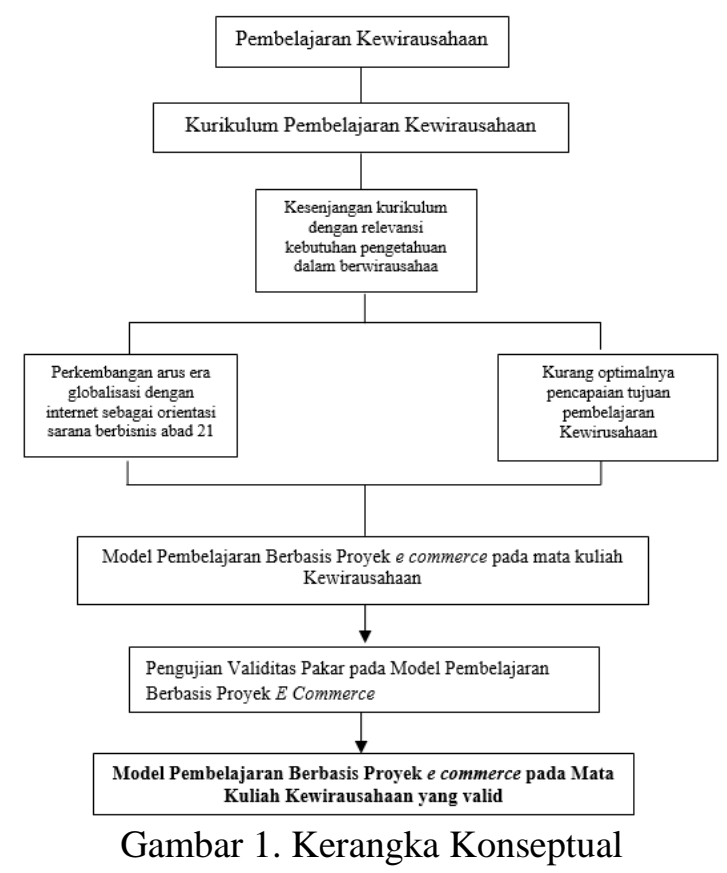

\section{METODE PENELITIAN}

Penelitian ini menggunakan metodologi penelitian dan pengembangan. Metode penelitian ini adalah penelitian dan pengembangan (research and deveopment). Penelitian pengembangan Model Pembelajaran Berbasis Proyek e commerce mata kuliah Kewirausahaan ini menggunakan desain pengembangan Four-D. Prosedur pengembangan dengan kerangka Four-D merupakan sistem permodelan yang kembangkan dari model-model sebelumnya yang berdasarkan pengalaman aktual terdiri dari tahapan merancang, mengembangkan, mengevaluasi, dan menyebarkan produk-produk instruksional dalam pendidikan dan pelatihan, model Four-D membagi proses pengembangan instruksional ke dalam empat tahap dari Define, Desing, Develop hingga Disseminate [20]. Fokus 
penelitian ini dibatasi pada peengukuran validitas model pembelajaran berbasis produk e commerce berdasarkan pendapat pakar yang dianalisis menggunaan data kuantitatif. Data Validasi materi diperoleh dari instrumen yang diisi oleh validator yang merupakan pakar pendidikan bidang Kewirausahaan, Pendidikan Kejuruan, Ekonomi, Bahasa dan Sastra, Teknologi Pendidikan dan Praktisi. Peneliti menganalisis hasil judgement expert menggunakan Koefisien validitas Aiken's V. Berikut Rentang angka $\mathrm{V}$ yang dapat diperoleh adalah antara 0 sampai dengan 1,00 maka jika skor $\mathrm{V} \geq 0,600$ dapat diinterpretasikan sebagai koefisien valid, sedangkan skor $\mathrm{V}<0.600$ dinyatakan sebagai koefisien penilaian yang tidak valid.

\section{HASIL PENELITIAN}

Temuan dalam penelitian ini adalah sebuah Model pembelajaraan untuk mata kuliah Kewirausahaan berbasis proyek e commerce. Model dicirikan dengan adanya tahapan-tahapan yang menjadi pedoman dalam menerapkan pembelajaran berbasis proyek. Pengembangan didasari dari kebutuhan akan model pembelajaran yang inovatif untuk mendukung pencapaian outcomes pembelajaran yang kewirausahaan pada era ekonomi digital. Sesuai dengan Design penelitian pengembangan yang digunakan berikut hasil penelitian:

\section{A. Define}

Tujuan dari tahap Define adalah untuk menetapkan dan menentukan persyaratan pengembangan instruksional. Pada tahap awal ini peneliti hanya melakukan analisis dengan tujuan untuk mengemukakan saran dan batasan untuk pengembangan instruksional yang dilakukan dengan lima tahapan yakni:

Berdasarkan analisis terhadap peserta didik yang dilakukan dengan wawancara dan observasi maka dapat disimpulkan bahwa a) mahasiswa memiliki pengetahuan dasar yang baik untuk melaksanakan proyek kewirausahaan dengan teknologi komputer dan pemanfaatan jaringan internet, b) mahasiswa memiliki sikap yang baik untuk menerima pembelajaran kewirausahaan yang sesuai dengan kompetensi keilmuan yang dimilikinya, dan c) mahasiswa memiliki kemampuan dasar dalam mengoperasionalkan media komputer dan menggunakan jaringan internet dalam berwirausaha. Oleh karena itu hasil analisis peserta (learner analysis) didik menyatakan bahwa model pembelajaran kewirausahaan berbasis proyek $e$ commerce dapat diterapkan kepada mahasiswa FKIP UPI YPTK Padang.

\section{B. Design}

Tujuan dari tahap Design adalah melakukan perancangan bahan atau prototipe dariModel Pembelajaran yang dikembangkan. Fase ini dapat dimulai setelah serangkaian tujuan perilaku untuk materi instruksional ditetapkan. Pemilihan media dan format pembelajaran merupakan aspek utama dari tahap perancangan. Uraian Syntax dari setiap fase pada Model Pembelajaran dapat dikemukakan sebagai berikut:

Fase 1: Supporting Class dan Comprehensive Theory. Memotivasi Kelas (Supporting Class) adalah kegiatan dimana Dosen mensupport mahasiswa untuk memiliki mind set wirausaha, meningkatkan ketertarikan mahasiswa dalam berwirausaha, mengemukakan kajian tentang mengapa berwirausaha serta wirausaha internet yang membuka peluang sukses berwirausaha melalui kisah sukses para wirausaha internet.

Fase 2: Determining Essensial Question (Perumusan Pertanyaan Essensial). Ditahap ini dosen memunculkan Rumusan Masalah dan pertanyaan Essensial untuk mendorong aktivitas kelas dalam proyek yang akan dikerjakan.

Fase 3: Project Discussion (Mendiskusikan Proyek). Fase ketiga dilaksanakan dengan diskusi kelas dan presentasi kelompok yang telah terbentuk. Bagianbagian proyek yang akan dikerjakan dalam tahapan yang akan datang dipresentasikan dan didiskusikan. Mahasiswa mengemukakan alternativ pemecahan masalah dalam wirausaha melalui kegiatan $e$ commerce.

Fase 4: Project Process (Proses Proyek) Fase ini terdiri dari kegiatan: Mentoring Praktisi (Support Exspert) dimana mahasiswa telah memiliki bekal berupa awal ide dan gagasan usaha yang akan dilakukan yang dituang melalui Business Plan yang dirancang mahasiswa.

Fase 5: Controlling Project Proses (Mengontrol Proses Proyek).Fase ini dilaksanakan dengan cara mahasiswa diminta mempresentasikan kemajuan dari tahap awal perencanaan projek yang telah mahasiswa lakukan.

Fase 6: Project Report(Pertanggungjawaban dan Laporan Akhir). Setelah melaksanakan proyek bisnis Online dalam kegiatan belajar yang terkontrol dan diawasi oleh dosen, mahasiswa dalam fase ini mengemukakan laporan pertangungjawaban akhir proyek.

Fase 7: Project Evaluation and Reflection (Evaluasi Project dan Refleksi). Fase Evaluasi dilakukan oleh dosen saat proses presentasi dilakukan selama proyek berjalan. 
Fase 8: Feedback Project (Umpan Balik Proyek). Fase akhir ini adalah fase dimana mahasiswa mengemukakan projek masa depan yang dapat direncanakan mahasiswa berdasarkan pengalaman yang telah didapatkan selama projek berlangsung.

Berdasarkan uraian dari Syntax yang telah dikemukakan maka dapat dijelaskan melalui Gambar Berikut ini:

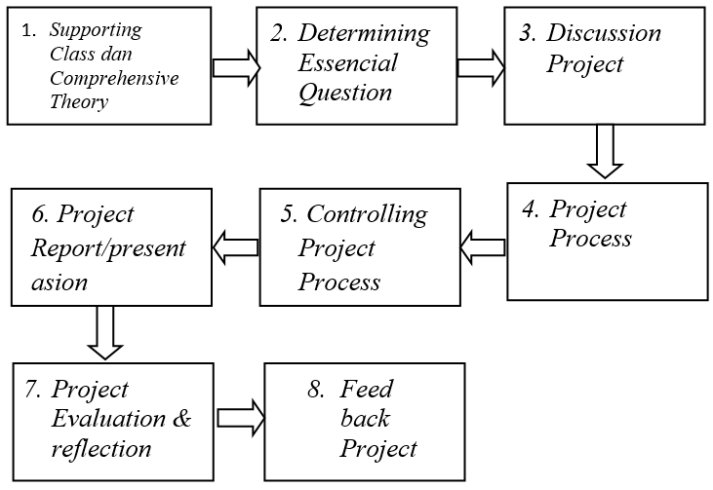

Gambar 2. Syntax Model Pembelajaran Berbasis

Proyek E Commerce pada mata kuliah Kewirausahaan

\section{Develop}

Develop dalam penelitian dilakukan dengan melakukan melalui tindak lanjut dari masukan hasil Forum Group Discussion dan Revisi Produk.
Dilaksanakan bertujuan untuk menggali informasi, memberikan masukan dan saran, serta mendiskusikan perangkat dan produk-produk pengembangan program Pembelajaran Kewirausahaan Berbasis Proyek e commerce. Tahap Develop merupakan tahapan dimana peneliti melakukan penilaian terhadap produk yang telah dikembangkan melalui pendapat pakar dalam penilaian formatif atau disaat proses pengembangan berlangsung. Penilaian yang dilakukan pakar selaku validator adalah terkait dengan aspek instruksional dan aspek teknis untuk menghasilkan model pembelajaran dengan isi dan struktur yang berkualitas tinggi. Evaluasi formatif yang baik akan menghasilkan penilaian yang konsisten dan tanggapan yang positif dari pakar yang memvalidasi. Berdasarkan hasil penilaian pakar maka dapat dijelaskan penilaian hasil Validasi Pakar pada masing-masing produk yang telah dikembangkan.

a) Validitas Intrumen Penilaian Validitasi dan Praktikalitas

Penilaian validator pada bagian ini adalah untuk memberikan penilaian (judgement) terhadap konten (isi) dari instrumen validitas yang akan digunakan untuk menjaring pendapat pakar tentang produk yang dikembangkan. Hasil validasi dapat dilihat pada Tabel 1

Tabel 1. Rangkuman Hasil Validasi terhadap Model Pembelajaran Kewirausahaan berbasis proyek e commerce

\begin{tabular}{lccc}
\hline \multicolumn{1}{c}{ Indikator } & $\begin{array}{c}\text { Skor } \\
\text { V Aiken }\end{array}$ & Ket. & $\begin{array}{c}\text { Hasil Aspek } \\
\text { Penilaian }\end{array}$ \\
\hline 1. Memiliki landasan berfikir berdasarkan teori yang relevan. & 0.90 & Valid & \\
2. Memiliki rasionalisasi pemikiran & 0.85 & Valid & Rasionalisasi \\
3. Memiliki alasan yang kuat berbasiskan masalah & 0.80 & Valid & Model \\
4. Memiliki rasionalisasi berdasarkan hakekat peserta didik & 0.85 & Valid & 0.85 (Valid) \\
5. Pengembangan merujuk kepada tujuan pembelajaran & 0.85 & Valid & \\
\hline 6. Menggunakan teori tentang model pembelajaran yang jelas. & 0.80 & Valid & \\
7. Penggunaan teori yang ringkas & 0.80 & Valid & Teori \\
8. Mendeskripsikan tentang operasional model. & 0.85 & Valid & Pendukung \\
9. Penjelasan tentang tujuan tujuan model yang dikembangkan. & 0.70 & Valid & Model \\
10. Memuat asumsi-asumsi teoritis. & 0.80 & Valid & 0.80 (Valid) \\
11. Memuat konsep-konsep utama sebagai dasar pegembangan & 0.70 & Valid & \\
\hline 12. Memiliki langkah-langkah kerja yang jelas & 0.70 & Valid & \\
13. Memiliki langkah kerja yang mudah dilakukan & 0.90 & Valid & \\
14. Memiliki langkah kerja yang mudah difahami & 0.70 & Valid & \\
15. Terdapat informasi dan urutan kerja pada setiap langkah. & 0.80 & Valid & Syntax Model \\
16. Sintak model realisitis untuk dilaksanakan & 0.70 & Valid & 0.78 (Valid) \\
17. Fase-fase menggambarkan prinsip pembelajaran proyek. & 0.80 & Valid & \\
18. Fase-fase dapat menjadi acuan kerja dosen & 0.80 & Valid & \\
19. Fase-fase sesuai karakteristik pembelajaran proyek & 0.85 & Valid & \\
\hline 20. Interaksi antara dosen dan mahasiswa terlihat secara jelas. & 0.80 & Valid & Sistem Sosial \\
21. Terdapat peran dosen sebagai fasilitator pebelajaran & 0.75 & Valid & 0.84 (Valid) \\
\cline { 2 - 4 }
\end{tabular}


22. Nampak jelas pola hubungan dosen dan mahasiswa.

23. Adanya peran dosen mendampingi mahasiswa dalam proyek

24. Melatih mahasiswa dalam berfikir dan penyelesaian masalah

25. Membentuk perilaku bertanggungjawab pada mahasiswa

26. Membentuk perilaku kerjasama antar mahasiswa

27. Mendorong mahasiswa dalam mewujudkan tujuan bersama didalam kelompok

28. Perilaku dosen pada model ini dinyatakan dengan jelas

29. Kegiatan dan kerja mahasiswa tersusun dengan jelas.

30. Peran dosen dan mahasiswa dinyatakan secara jelas dan rinci.

31. Kegiatan pembelajaran tersusun dengan jelas

32. Buku panduan dosen mendukung kegiatan pembelajaran.

33. Buku panduan dosen dapat mendukung tujuan pembelajaran.

34. Kegiatan dalam modul tersusun dengan jelas

35. Materi modul sesuai untuk mendukung pelaksanaan model

36. Modul menggunakan lembar tes/evaluasi sesuai dengan tujuan pembelajaran.

37. Media peraga Web Store mendukung pelaksanaan model

38. Media peraga web store sesuai dengan kebutuhan model

39. Dampak Instruktional sesuai dengan tujuan pembelajaran yang ingin dicapai.

40. Uraian dampak instruktional dinyatakan dengan jelas

41. Dampak pengiring menunjukkan arah tujuan pembelajaran

42. Model memiliki dampak pengiring yang bermanfaat untuk peningkatan kualitas nilai-nilai berwirausaha bagi mahasiswa.

43. Cakupan dampak instruktional dan pengiring logis

44. Memiliki dampak pengiring peningkatan kreativitas berpikir

45. Memiliki dampak ekonomis bagi mahasiswa

46. Memiliki dampak merubah mind set dalam berwirausaha

47. Mengembangkan kemampuan dalam menciptakan usaha dalam praktik berwirausaha secara nyata

48. Meningkatkan kemampuan penguasaan teknologi dalam $0.80 \quad$ Valid

$\begin{array}{ll}0.90 & \text { Valid } \\ 0.95 & \text { Valid } \\ 0.80 & \text { Valid } \\ 0.90 & \text { Valid } \\ 0.85 & \text { Valid } \\ 0.80 & \text { Valid }\end{array}$

$0.85 \quad$ Valid

$0.80 \quad$ Valid

$0.85 \quad$ Valid

Prinsip Reaksi

0.83 (Valid)

$0.80 \quad$ Valid

$\begin{array}{ll}0.80 & \text { Valid } \\ 0.85 & \text { Valid }\end{array}$

$0.90 \quad$ Valid

$0.85 \quad$ Valid

Sistem

$0.80 \quad$ Valid

Pendukung

0.84 (Valid)

$0.90 \quad$ Valid

$0.80 \quad$ Valid

$0.95 \quad$ Valid

$\begin{array}{ll}0.85 & \text { Valid } \\ 0.85 & \text { Valid } \\ 0.90 & \text { Valid }\end{array}$

$0.85 \quad$ Valid

$0.95 \quad$ Valid

$0.85 \quad$ Valid

$0.85 \quad$ Valid

$0.95 \quad$ Valid

Dampak

Instruksional

dan Dampak

Pengiring

(0.87) Valid berwirausaha

Berdasarkan tabel hasil uji validitas terhadap instrument validasi dari validator adalah: 1) Aspek rasionalisasi model memiliki skor rata-rata 0.85 dengan kategori valid, 2) Aspek teori pendukung memiliki skor rata-rata 0.80 dengan kategori valid, 3) Aspek Syntax memiliki skor rata-rata 0.78 dengan kategori valid, 4) Aspek sistem sosial memiliki skor rata-rata 0.84 dengan kategori valid, 5) Aspek prinsip reaksi memiliki skor rata-rata 0.83 dengan kategori valid, 6) Aspek system pendukung memiliki skor rata-rata 0.84 dengan kategori valid, 7) Aspek dampak instruksional dan dampak pengiring memiliki skor rata-rata 0.88 dengan kategori valid. Dengan demikian Model Pembelajaran Kewirausahaan pada era Internet yang telah dikembangkan dinyatakan valid dari semua aspek penilaian. Validasi ini dilakukan oleh lima orang para ahli (expert) atau validator.

\section{Disseminate}

Berikut bentuk tahapan-tahapan yang ada pada model pembelajaran berbasis proyek e commerce: a) Packaging, setelah proses evaluasi summative yang menjadi bagian dari tahap Disseminate dilakukan maka tahapan selanjutnya adalah melakukan pengemasan (packaging). Hal ini bertujuan untuk menyempurnakan proses pengembangan yang telah dilakukan melalui tahapan penyebarluasan hasil pengembangan.

\section{PEMBAHASAN}

Munculnya fenomena perubahan perilaku berbisnis pada era globalisasi yang pada dasarnya telah mempengaruhi pergeseran bentuk-bentuk kegiatan dalam Kewirausahaan. Oleh karena itu pengembangan dan inovasi dalam pembelajaran harus dilakukan agar proses dalam pendidikan Kewirausahaan tidak menjadi hal yang sia-sia 
karena telah dilakukan sesuai dengan kebutuhan mahasiswa dalam berwirausaha, karena belajar merupakan suatu aktivitas yang kompleks, hasil belajar merupakan sebuah kapabilitas dimana seseorang akan memiliki keterampilan-keterampilan, sikap dan nilai-nilai, timbulnya kapabilitas tersebut adalah dari stimulasi yang berasal dari lingkungan dan proses kognitif yang dilakukan oleh pembelajar. Berdasarkan analisis pada tahap Define yang telah dilakukan dapat digambarkan bahwa permasalahan utama dalam pembelajaran Kewirausahaan adalah bahwa masih rendahnya relevansi konten pembelajaran dengan kebutuhan untuk berwirausaha pada era globalisasi dengan adanya kehadiran internet yang telah merubah femomena cara berwirausaha melalui munculnya fenomena wirausaha internet. Internet telah mempermudah proses kegiatan wirausaha dengan membuka peluang melakukan kegiatan berwirausaha melalui jaringan internet, seperti yang dikemukakan Kende yang menyatakan bahwa "terbukanya akses Internet telah menciptakan terbukanya peluang bisnis keseluruh dunia" [21]. Hal ini menyebabkan bahwa internet memiliki dampak pada penciptaan segmen baru kegiatan berwirausaha memulai usaha secaraonline, sehingga mahasiswa yang menjadi calon wirausaha harus mampu menetapkan dan menargetkan pasar secara global agar mampu menjadi pelaku wirausaha melalui internet.

\section{KESIMPULAN}

Penilaian yang dilakukan pakar selaku validator adalah terkait dengan aspek instruksional dan aspek teknis untuk menghasilkan model pembelajaran dengan isi dan struktur yang berkualitas tinggi. Hasil penilaian validitas menyatakan bahwa 1) Validitas Intrumen Penilaian Validitasi dan Praktikalitas memiliki kriteria valid pada seluruh aspek penilaian, 2) Model Pembelajaran Berbasis Proyek $E$ Commerce pada mata kuliah Kewirausahaan memiliki kriteria valid pada seluruh aspek penilaian, 3) Modul Pembelajaran Kewirausahaan Berbasis Proyek E Commerce memiliki kriteria valid pada seluruh aspek penilaian, 4) Pedoman Mengajar Kewirausahaan Berbasis Proyek E Commerce memiliki kriteria valid pada seluruh aspek penilaian, 5) Media Peraga Website E Commerce memiliki kriteria valid pada seluruh aspek penilaian. Hasil validitas produk dalam pengembangan model pembelajaran Kewirausahaan berbasis proyek commerce ini dinyatakan bahwa seluruh produk memiliki telah valid, dan dinyataka produk-produk hasil penelitian ini layak digunakan, dan kemudiak diujicobakan pada tahap selanjutnya untuk menilai kepraktisan produk

\section{DAFTAR PUSTAKA}

[1] Unesco. 4 Pilar Pendidikan. Diakses melalui http://akhmadsudrajat. wordpress.com, /2008/05/08/empat-pilar-belajar. Pada tanggal 10 Maret 2016.

[2] Jalinus, N., Arwizet, K, Nabawi, R. A. and Ambiyar. "Improve Learning Outcomes of Students Through Implementation of The Collaborative Project-Based Learning Model in Thermodynamics." Proceeding the lst International Conference on Education Innovation. Vol. 1. No. 1. 2017.

[3] Brennan, J, King,R. \& Lebea, Y. The Role of Universities in the Transformation of societies. London: Centre of Higher Education Research anf Information/Association of Commonwealth Universitas. 2004.

[4] Siddoo V, Sawattawee J, Janchai W, \& Yodmongkol. Esploring the Competency Gap of It Students in Thailand: The Employers View of an Effective Work Force. Journal of Technical Education and Training (JTET). Vol. 9, No.2. 2017.

[5] Jiwa, Salim dkk. E-Entrepreneurship:Learning in a Simulated Environment. Journal of Electronic Commerce in Organizations edited by Mehdi Khosrow-Pour. http://www.idea-group.com. 2005.

[6] Haywood, John. Engineering Education Research and Developmentin Curriculum and Instruction. A. JOHN WILEY \& SONS, INC., PUBLICATION. IEEE Press Editorial Board. 2005.

[7] Lung-Tan Lu Shing-Ko Liang. Road to Initial Public Offerings (IPO): A Case of Internet Entrepreneur In Taiwan. International Journal Of Science Research And Technology Volume 2 Issue 3. PP 9-14. 2016.

[8] Stevens, Nicholas. Online Trust \& Internet Entrepreneurs: A Kantian Approach. Scholarly Commons Wharton Research Scholars Wharton School. 2010.

[9] Zimmerer, T. W., Scarborough, N.M., \& Wilson, D. Essentials of entrepreneurship and small business management (4th ed.). New Jersey: Pearson Education, Inc. 2008.

[10] Kuratko., Donald., \& Hodgetts, R. Enterpreneurship: Theory, process and practice (6th ed.). Canada: Thomson South-Western. 2004.

[11] Rahyubi, Heri. Teori-teori Belajar dan Apilkasi Pembelajaran Motorik. Deskripsi dan Tindakan Kritis.Bandung. Nusa Media. 2012.

[12] Joyce Bruce, Weil Marhsa \& Emily Calhoun. Models of Teaching Model-model Pengajaran. Yogyakarta. Pustaka Pelajar. 2009.

[13] Arends, R.I. Classroom Instruction and Management. New York: The McGraw-Hill Companies, Inc. 1997.

[14] Mahanal S. Pengaruh Pembelajaran Project Based Learning pada Materi Ekosistem terhadap sikap 
dan Hasil Belaja Siswa SMAN 2 Malang. Jurnal Sains 1-10. 2009.

[15] Jalinus, N. Nabawi, R. A. dan Mardin, A. The seven step of the project based learning model to enhance productive competences of vocational students. Proceedings of the International Conference on Technology and Vocational Teacher (ICTVET 2017). Vol. 102. pp 251-256. 2017.

[16] Nath, R., \& Murthy, N. R. V. An Examination Of The Relationship Between Digital Divide And Economic Freedom: An International Perspective, Journal of International Technology and Information. 2003

[17] Wirayuda, Nur Hasan. Perbedaan e commerce dengan e business. Dikutip dari http://www.gatlingkom.com/2016/10/perbedaan-ecommerce-dan-e-business.html. 2016.

[18] O'Reilly, T. What's next for web 2.0, O'Reilly. Viewed August 12, 2011, from http://oreilly.com/web2/archive/what-is-web20.html. 2009.

[19] Sulianta. Feri. Transaksi Online dalam dan Luar Negeri. Jakarta. Elex Media Computindo. 2014.

[20] Sivasailam, Thiagarajan, dan Semmel, D, S. Instructional Development for Training Teachers of Exceptional Children: A Sourcebook. National Center for Improvement of EducationalSystems (DHEW/OE), Washington, D. C. A joint publication of the Leadership TrainingInstitute/Special Education, University of Minnesota. 1974.

[21] Kende, Michael. ICTs for Inclusive Growth: EEntrepreneurship on the Open Internet. The Global Information Technology Report. ketiga). Jakarta: Kencana Prenada Media Group. 2015. 